\title{
A Review of Roof and Pond Rainwater Harvesting Systems for Water Security: The Design, Performance and Way Forward
}

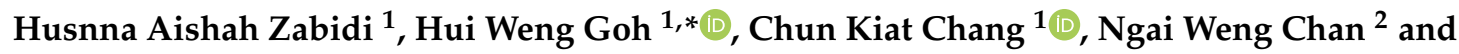 \\ Nor Azazi Zakaria ${ }^{1}$ \\ 1 River Engineering and Urban Drainage Research Centre (REDAC), Engineering Campus, \\ Universiti Sains Malaysia, Nibong Tebal 14300, Penang, Malaysia; husnnazabidi@gmail.com (H.A.Z.); \\ redac10@usm.my (C.K.C.); redac01@usm.my (N.A.Z.) \\ 2 School of Humanities, Universiti Sains Malaysia, Gelugor 11800, Penang, Malaysia; nwchan1@gmail.com \\ * Correspondence: redac_gohhuiweng@usm.my
}

Received: 22 September 2020; Accepted: 9 November 2020; Published: 12 November 2020

\begin{abstract}
Rapid urbanization, population explosion and climate change have threatened water security globally, regionally and locally. While there are many ways of addressing these problems, one of the innovative techniques is the recent employment of Sustainable Urban Drainage Systems (SUDS) which include rainwater harvesting systems (RWHS). Therefore, this paper reviews the design and component of two types of RWHS, the namely roof harvesting system (RHS) and the pond harvesting system (PHS). The performance in terms of quantity and quality of collected rainwater and energy consumption for RWHS with different capacities were evaluated, as well as the benefits and challenges particularly in environmental, economic and social aspects. Presently, the RHS is more commonly applied but its effectiveness is limited by its small scale. The PHS is of larger scale and has greater potentials and effectiveness as an alternative water supply system. Results also indicate the many advantages of the PHS especially in terms of economics, environmental aspects and volume of water harvested. While the RHS may be suited to individual or existing buildings, the PHS has greater potentials and should be applied in newly developed urban areas with wet equatorial climate.
\end{abstract}

Keywords: water security; sustainable urban drainage system; stormwater management system; pond harvesting system; roof harvesting system; rainwater harvesting; domestic water demand

\section{Introduction}

Water security can be described as protecting the human societies against the negative impacts of water scarcity and excess, as water is precious to human life and development [1]. In recent decades, climate change has impacted the availability of freshwater and groundwater, which has affected water security [2]. Climate change tends to change the rainfall frequency and intensity, and this has led to the change of the balance between dry and wet periods. For example in Malaysia, Tan et al. [3] reported that every region is expecting increase in mean precipitation and temperature compared to historical data, where the trend of extreme wet days of Peninsular Malaysia was found to increase in the north-east [4] and decreased in the north-west [5] during the period 1985 to 2015. The change of the balance between wet and dry periods has not only caused water shortage issues during the extended dry period, it has also increased the flood risk due to increased rainfall intensity and created problems for various sectors, such as the agriculture, forestry and energy sectors. Therefore, to overcome these problems, sustainable stormwater management has become one of the enablers to achieve Sustainable Development Goals (SDG) as well as for enhancing climate resilience (as an adaption to climate 
change). Sustainable stormwater management also produces better ecosystem services that integrate the management, restoration and sustainability of natural infrastructure to ensure availability and sustainable management of water and sanitation for all.

In past decades, the application of stormwater management system, particularly conventional drainage systems, has only focused on water quantity control. Increasingly, however, sustainable stormwater management necessitates the incorporation of other vital aspects in urban water management, such as runoff quality, visual amenity, recreational value, ecological protection and multiple water uses [6]. The related literature has shown the development and adoption of a range of new terms, with the purpose of illustrating integrated stormwater management towards a more holistic approach, by involving the management of stormwater, grey water and wastewater. Several terms have been widely introduced, such as Low Impact Development (LID) [7], Sustainable Urban Drainage Systems (SUDS) [8], Best Management Practices (BMPs) [9], the Manual Saliran Mesra Alam (MSMA) Management Strategy [10] and Water Sensitive Urban Design (WSUD) [11]. In Europe, SUDS have been applied as best practices with aim to maintain good public health, protect the valuable water resources from pollution as well as preserving biological diversity and natural resources for future necessity [12]. For some other countries like in the United States and Canada, SUDS were described as LID or BMPs [7-9], whereas in Malaysia, the term MSMA Management Strategy is used [10] and in Australia the term WSUD is preferred [11]. In fact, all the terms and approaches will not achieve the sustainable development if the water security has been neglected. Hence, SUDS have included a range of drainage techniques and devices, that allows runoff attenuation and mitigation, pollutant reduction and amenity construction [13] to converse water security with the acceptable quantity and quality of water health, livelihood and production as well as water related-risk, such as filter and infiltration trenches, permeable surfaces, swales, water harvesting, detention basins and wetlands [14].

Among all the SUDS devices, the Rainwater Harvesting System (RWHS) is one of the techniques that is close to the community in tackling water scarcity and efficient in reducing the runoff volume [15], which has increasingly gained interest among the community for the last 20 years. According to United Stated Environmental Protection Agency (USEPA), the Rainwater Harvesting System (RWHS) is defined as "collecting rainwater from impervious surfaces and storing it for later use" [16]. The function of the system is solely to collect and save rainwater from rooftops, land surfaces, road surfaces or rock catchments [17]. This system is normally implemented either using a simple technique like pots, tanks and cisterns, or a complex technique, such as underground check dams. Collected rainwater will then be used as a non-potable water supply, for instance for toilet flushing, laundry and car washing [18]. Besides usage as a non-potable resource, harvested rainwater was also known as a renewable source for clean water and it can be applied for drinking water and potable demands $[19,20]$. Besides domestic water demand that fulfill by Roof Harvesting System (RHS) on a small scale, the irrigation water demand also could be fulfilled by using the Pond Harvesting System (PHS), which is on a bigger scale of RWHS.

Despite the successful application of RWHS in countries with relatively less annual rainfall, this technique was less implemented in countries with higher rainfall due to an abundance of water resources in their countries. In fact, water security has become a risk in recent years, as climate change has changed the dry and wet periods considerably, leading to an imbalance in water availability throughout the year, with prolong dry periods and more frequent extreme rainfall [21]. As a result, the mismatch between water demand and rainfall (water availability) has resulted in the high variability of water resources in highly developed and populated areas like Selangor, Putrajaya and Kuala Lumpur in Malaysia, often leading to flash floods and water shortage issues [22]. Such issues became the main concern that opened the eyes of many authorities and researchers to turn their attention to engage in the practice of SUDS. Thus, the introduction of SUDS through RWHS to the high rainfall countries has begun by using the RHS application, to reduce the flood risk and fulfil the water demand. However, the same benefits that can be gained in term of the bigger perspective through the PHS application have never been exploited before, even if it is for implementation in the countries with a high amount of rainfall and plenty of unused land. 
Therefore, the aims of this review paper are: (1) to review the types of RWHS design, their components and current performance in terms of rainwater quantity and quality as well as energy and economic savings (2) to suggest the way forward in RWHS implementation and to identify the future potentials of PHS application for better water security.

\section{System Design and Its Components}

\subsection{Categories of RWHS}

RWHS can be divided into two categories, namely the roof harvesting system (RHS) and pond harvesting system (PHS). The RHS is more well-known and has been applied in the countries such as Jordan [19], Spain [23], Italy [24], Australia [25], Ireland [26] and Malaysia [20]. Harvested rainwater from the RHS is usually used to facilitate both non-potable and potable water demands. There are two types of storage tanks for an RHS, which are aboveground (Figure 1a) and underground storage (Figure 1b). Meanwhile, the storage for PHS (Figure 2) is a reservoir that is normally located close to the crop field with the purpose of enhancing and supplementing irrigations [27], especially during the critical period of crop growth or for extending the growing season.

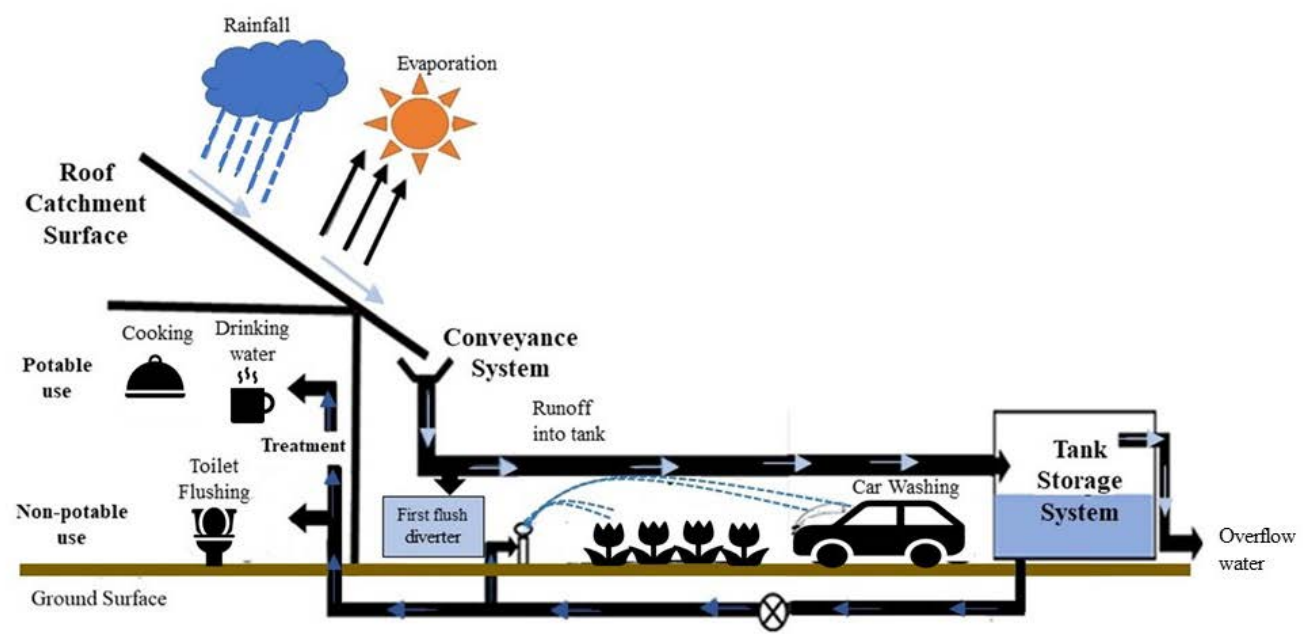

(a)

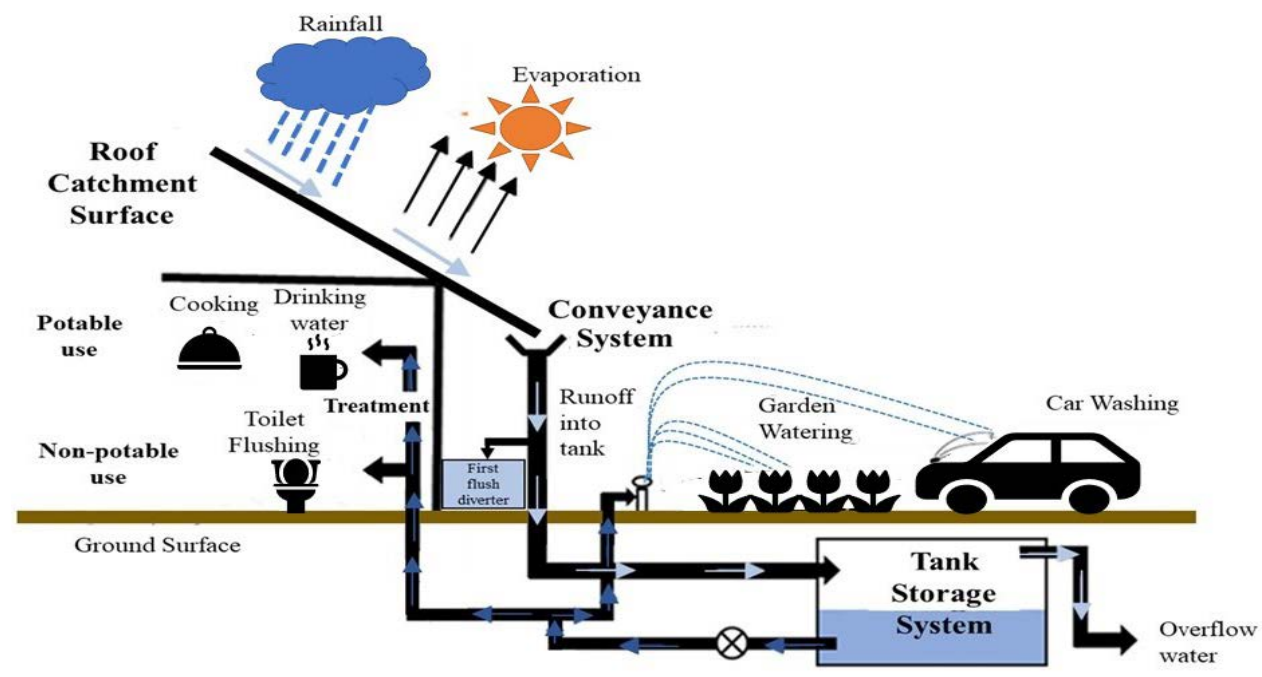

(b)

Figure 1. Design of a roof harvesting system (RHS). (a) Aboveground storage. (b) Underground storage. 


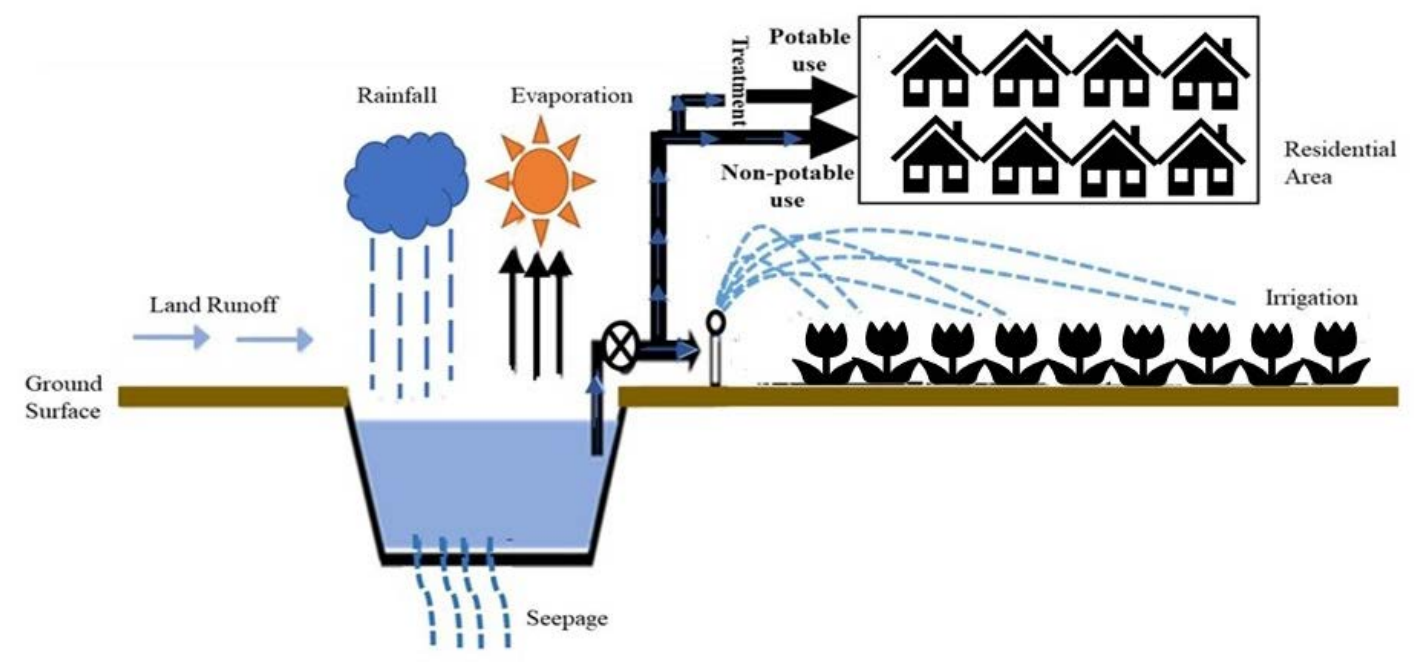

Figure 2. Design of a pond harvesting system (PHS).

\subsection{Components of RWHS}

Generally, RWHS consist of three fundamentals components: catchment surface, conveyance system and storage system. In RWHS, the catchment surface should be efficient in conveying surface runoff to accumulate into the storage tank or pond storage. The RHS allows the collection of rainwater from the impervious surface of a rooftop, while the PHS harvests the rainwater from the pervious land surface. In the RHS, the material used for the roof catchment surface will significantly influence the effectiveness and quality of collected rainwater. A roof type that is smooth, clean and impervious is preferable [26]. Some examples are asphalt shingle and flat tar roofs used in Ontario, Canada [28], clay tile and flat roofs in Mediterranean landscape [23] and zinc roofs in Penang, Malaysia [29]. Unlike the RHS, the PHS needs a catchment where the runoff can be easily captured such as a public area, roads, or common land [30].

The function of the conveyance system in the RHS is to transfer the rainwater from the rooftop catchment into the storage tank, which normally includes the gutters and downpipes. These gutters and downpipes are usually made with the different materials, for example plastic or metal in Jordan [19] or galvanized steel, stainless steel and fiberglass types in Ireland [26]. On the other hand, the PHS does not require any conveyance system, as the runoff from the catchment area flows to the pond storage using gravitational force.

The storage system in RWHS is used to store the collected rainwater with a minimal storage tank below a hundred $\mathrm{m}^{3}$. For the RHS, the storage tanks can be built in multiple ways with different materials, sizes and shapes. For example, plastic or concrete are used as common storage tank materials in Jordan [19], while cement-brick and metal are widely used in Ireland [26]. For aboveground storage tanks (Figure 1a), they are good for minimizing the cost and allowing gravity flow to be used in extracting the harvested rainwater [17]. The tank cleaning and detection of leakage and cracks is also easier as compared to when using underground storage tanks. On the other hand, the underground storage tank (Figure 1b) is better at maintaining a cool temperature of the collected rainwater and it also preserves the aboveground space for other purposes. However, the underground storage tank has some disadvantages in extracting the water (a pump is needed), difficulty in detecting leakage or cracks, risk of contamination and a higher cost of construction [26].

For most of the storage systems in the PHS, the soil is used as the basic structure with designed large pond storage systems ranging from a hundred to a thousand $\mathrm{m}^{3}$. Unlike the RHS that uses enclosed storage systems, storage for the PHS is an open system where the collected water is subject to losses due to seepage into the subsurface of soil and evaporation. Therefore, additional methods need to be implemented, for example a design with a lining, covered with corrugated items and built with a silt trap. The lining is built using plastic sheets or concrete with the purpose of minimizing the 
seepage losses of water captured into the soil subsurface [31]. Sometimes, the reservoir is covered by a corrugated plate or plastic sheet to decrease the evaporation losses. Other than that, the PHS is also constructed with a lined or unlined silt trap which is located at the entrance of the storage system to avoid siltation and a spillway that controls the discharge of excess runoff [32].

\section{Performance of RWHS}

This section will discuss the performance of RWHS, particularly water quantity and quality as well as energy and economic savings.

\subsection{Water Quantity}

\subsubsection{Peak Flow Reduction}

The common strategy of the SUDS to include the water quantity element has been facilitated by RWHS, where RWHS are a stormwater control measure that provides water supply at the same time. It has the potential to reduce the peak discharge and heavy rainfall, as the systems were designed by diverting the precipitation runoff to the area where it can be used or stored. Table 1 illustrates the volume reduction in precipitation runoff under different capacities of storage tank. Case studies in China [33], Italy [34] and South Korea [35] have reported that the runoff volume was reduced between $9 \%$ and $57.7 \%$ using a storage tank that sized between 139 and $4083 \mathrm{~m}^{3}$ (except for South Africa [36]). According to Basinger et al. [37], appropriate usage of tank size for the RHS could decrease the annual runoff but it could not eliminate it totally. However, Coombes et al. [38] reported a contradiction, where the RHS can completely eliminate the runoff. This contradiction may be due to dissimilar precipitation in both places, the size of RWHS used or different methodologies of RWHS analysis.

Table 1. Summary of the case studies for runoff reduction by rainwater harvesting systems (RWHS).

\begin{tabular}{|c|c|c|c|c|}
\hline Country & Storage Tank $\left(\mathrm{m}^{3}\right)$ & $\begin{array}{c}\text { Annual } \\
\text { Rainfall (mm) }\end{array}$ & Rainfall Runoff & References \\
\hline China & 4083 & $1106^{* *}$ & $\begin{array}{c}\text { decreased } 13.9 \%, 30.2 \% \text { and } 57.7 \% \text { for } \\
\text { maximum daily rainfall, annual average } \\
\text { maximum daily rainfall and critical rainfall, } \\
\text { respectively, in Nanjing }\end{array}$ & Zhang et al. [33] \\
\hline Italy & N/A & $1086^{* *}$ & decreased $26 \%$ of runoff volume in Genoa & Palla et al. [39] \\
\hline \multirow{2}{*}{ United States } & N/A & 1016 ** & $\begin{array}{c}\text { decreased } 28 \% \text { of runoff volume in New } \\
\text { York city }\end{array}$ & Basinger et al. [37] \\
\hline & N/A & 1600 * & $\begin{array}{l}\text { decreased more than } 20 \% \text { runoff volume in } \\
\text { Florida Panhandle }\end{array}$ & Deitch and Feirer [40] \\
\hline
\end{tabular}

Note: $*$ is the annual rainfall stated in the reference. ${ }^{* *}$ is the annual rainfall compiled from officially recognized sources.

The peak flow rate is the most important parameter to avoid flood risk where RWHS application has the potential to reduce the peak flow rate for a great number of events, depending on the tank capacity and rainfall characteristics. A study by Fisher-Jeffes et al. [36] showed that the RHS can decrease more than $50 \%$ of peak flow rate for more than a $50 \%$ event with a recurrence interval (RI) of less than 1 week, but the efficiency starts to fall when the RI increases. For events with a return period of 3 months, the peak flow reduction is less than $2 \%$ for $17 \%$ of events and less than $10 \%$ for $58 \%$ of events. This is also supported by Petrucci et al. [41] who conducted a similar study in eastern Paris. 
For the PHS, the selection of a site with high to moderate runoff was chosen as the most suitable area [42], where it can harvest more rainwater and is able to reduce the flood risk. For a case study in Iraq, Amedi, Zaxo and Akre were identified as the suitable areas for harvested rainwater as these area present with maximum rainfall rates of $949 \mathrm{~mm}$, located at downstream sites of the watershed and have dense hydrological networks with slopes less than three compared to the unsuitable area allowing a large excess of rainfall that led to the availability of runoff to be gathered [43]. Average peak flow reduction by the PHS was found for all events with a return period of one year or greater than ten years [44]. This is due to the PHS design that can significantly reduce peak flow for smaller events as all the flow events were detained with the allowable pond conditions. Besides peak flow reduction, PHS application also assists in adjusting the imbalance of hydrological cycles and groundwater recharge in urban areas as the design allows a large amount of rainwater to be collected. Therefore, PHS application has great potential in humid tropical countries that experience changes of rainfall pattern that cause imbalance in water availability during dry and wet seasons.

\subsubsection{Water Supply}

The runoff that is diverted into storage for RWHS application is not wasted as is used for the water supply. Table 2 summarized the RHS case studies in various countries to compare their water supply capacity under different annual rainfall (annual rainfall consists of two pieces of information, where the first column is the annual rainfall from the conducted case studies and the second column is the annual rainfall from the meteorology department of each country for the purpose of verification). It shows that the RHS can fulfill most of the domestic water demand and this helps to minimize the dependency on the conventional water supply. For case studies in developed countries such as Australia [25], Greece [45], United States [37], Poland [46] and Taiwan [47], the RHS is able to meet the domestic water demand between $50 \%$ and $90 \%$, with the reported size of the storage tank ranging between 5 and $76 \mathrm{~m}^{3}$. For developing countries such as Bangladesh [48], Malaysia [20,29,49] and Southwestern Nigeria [50], the case studies shows that the domestic water demand that can be achieved is slightly lower than in developed countries ( $30 \%$ to $80 \%$ ), although the reported size of the storage tank is generally higher (except for Brazil [51,52] and Colombia [53]). For a case study in Jordan [19], the domestic water demand that can be achieved is extremely high, which is around $145 \%$, due to a larger storage area that is able to harvest a high amount of rainwater from the rooftop and an open area of roads and parking lots.

Table 2. Summary of the roof harvesting system (RHS) case studies in developed and developing countries for comparison of water supply capacity under different annual rainfall amounts.

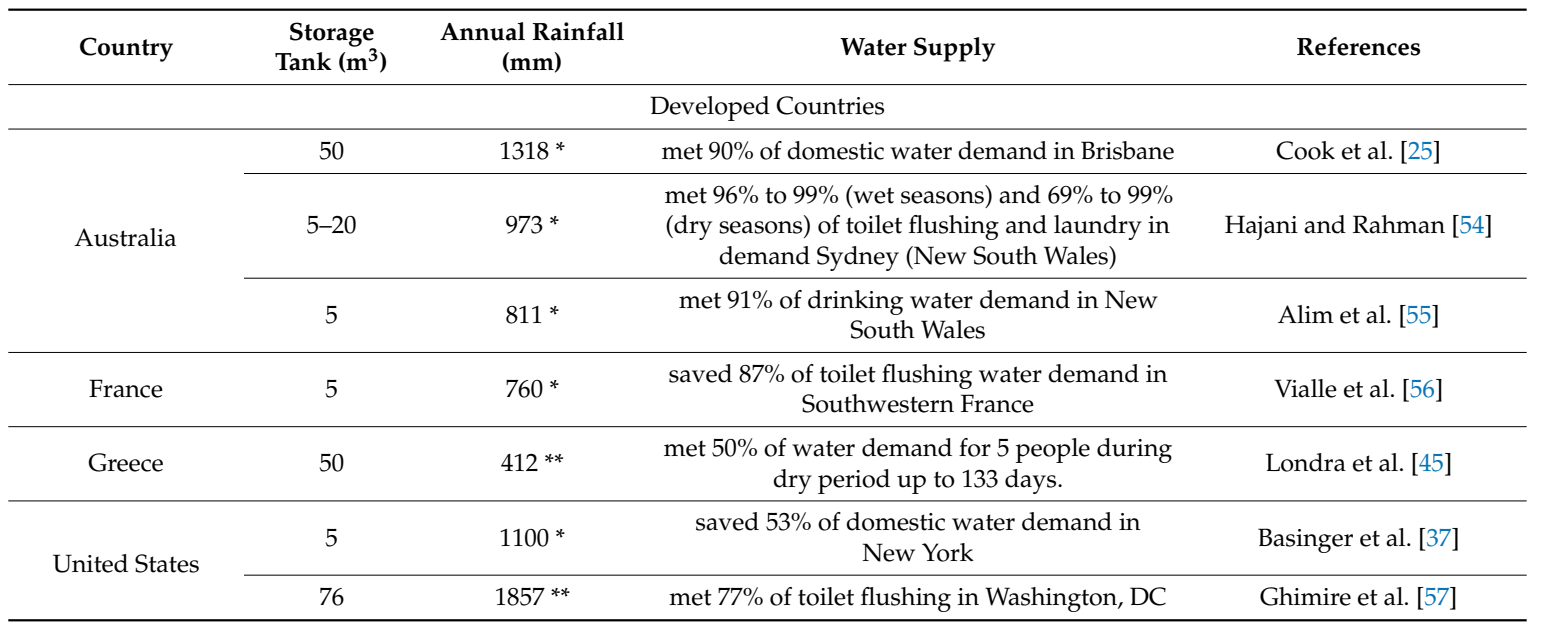


Table 2. Cont

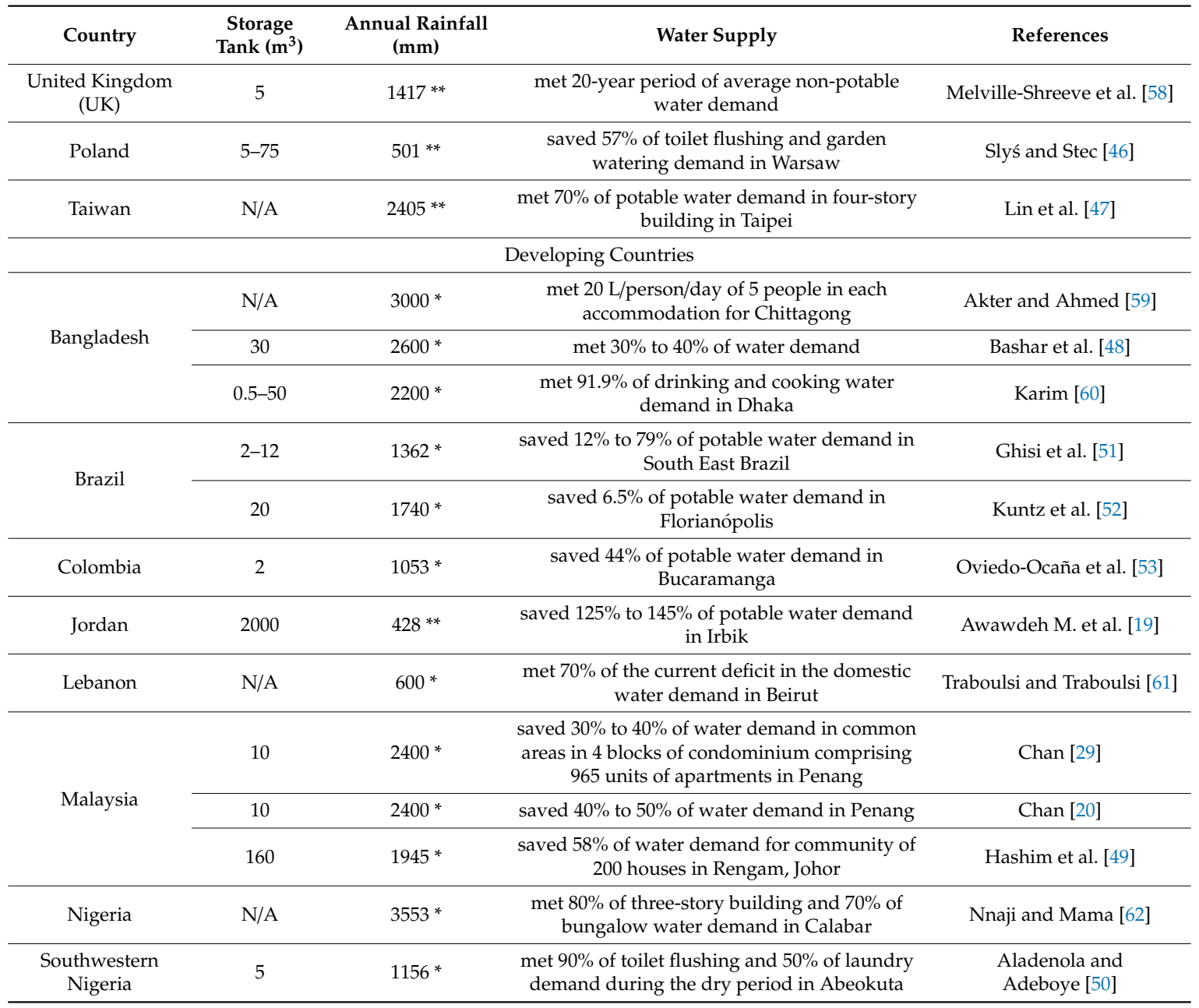

Note: $*$ is the annual rainfall stated in the reference. ${ }^{* *}$ is the annual rainfall compiled from officially recognized sources.

From the case studies, it is shown that in most developed countries, the RHS is implemented mainly for non-potable uses while, for developing countries, it is also implemented for potable uses, often as drinking water. This difference of usage may be attributed to easy access to the conventional water supply, the higher average income of consumers and affordable water tariffs in developed countries [35]. Overall, the harvested rainwater from RHS is able to meet more than half of the non-potable water demand, such as toilet flushing (around 70\% to 90\%), laundry (between 50\% and 90\%) [50,63] and garden watering (57\%) [46]. For potable use, the case study in Australia showed that about $91 \%$ of drinking water demand was achieved and about $91.9 \%$ of drinking and cooking water demand was achieved in Bangladesh $[55,60,64]$.

The case studies of the PHS for dependency on irrigation and domestic demand in various countries are presented in Table 3. It is indicated that the PHS can meet an average of $50 \%$ of the irrigation demand, with the pond storage capacity ranging from a hundred to a thousand $\mathrm{m}^{3}[57,65,66]$. The case study in Ethiopia showed that the PHS can only fill up to $5 \%$ of domestic water demand, as the harvested rainwater was mainly used to fulfill the irrigation demand [67]. In contrast, for the PHS case study in India, it can meet almost up to $100 \%$ of drinking water demand, at $40 \mathrm{~L}$ cubed per demand (lcpd) of the 1632 population due to the fact that the PHS was constructed as a drinking water pond [32].

The case studies have shown that the opened systems of PHS could cause massive water loss through seepage and evaporation. For example, the water loss in Eastern India is around 
$8 \%$ (evaporation) and 30\% (seepage) [68] and in Laikipia around 30\% to 50\% [69]. According to Pandey et al. [70], the smaller the size of the PHS, the higher the seepage loss compared to evaporation loss and vice versa for the larger size of PHS. This shows that inappropriate selection of the targeted site, such as regarding soil type and climate condition will cause a higher amount of water loss [30]. Therefore, by using the additional method of pond lining, such as the plastic or geo-membrane in Ethiopia [67] and the retaining wall in India [32], the amount of water loss can be reduced.

For a tropical climate country such as Malaysia that is relatively rich in water resources (annual rainfall is estimated to be $2400 \mathrm{~mm}$ in the peninsular area), it has never had water crisis issues for the past few decades. However, climate change is predicted to decrease the future rainfall in several states in Malaysia to as low as $32 \%$ to $61 \%$ of average monthly rainfall, particularly during the dry season from May to August [71]. Therefore, many studies and much research have been conducted on RHWS to reduce the dependency on water resources and hold back water crisis especially during the dry seasons, but most of the studies only focused RHS application $[20,29,49]$ and the potential of PHS application in Malaysia has not been fully discovered, although it has a bigger storage capacity to accommodate the larger community.

With the current application of the PHS which is only restricted to rural areas and mainly used for irrigation, there is a need to explore PHS application in urban areas, especially with the current new development that is centered on nature-based solutions (NBS), a concept defined by the International Union for Conservation of Nature as "a sustainability of natural or modified ecosystem while providing benefits for human well-being" [72]. One of the examples of an NBS project is constructed wetlands, which have been applied as a HYDROUSA project in Mediterranean regions [73], Gorla Maggiore Wetland in northern Italy [74] and the Bio-Ecological Drainages System (BIOECODS) Project in Malaysia [75]. Taking BIOECODS as an example, the system consisting of several types of ponds which are a dry pond, wet pond, detention pond, wetland and a recreational pond [75] serving to reduce runoff rates, runoff volume and pollutant load. The recreational pond that detains treated rainwater has great potential as PHS application to fulfill the domestic water demand. Under the same practices of BIOECODS, the current policy is that every new development in Malaysia should allocate 3\% of the $10 \%$ green area [76] for the pond which also has potential to maximize its usage as a PHS as well as to save the domestic water demand and it is applicable to be practiced in the other countries of tropical climate.

Table 3. Summary of case studies for the water supply capacity of the pond harvesting system (PHS).

\begin{tabular}{|c|c|c|c|c|c|c|}
\hline \multirow{2}{*}{ Country } & \multirow{2}{*}{$\begin{array}{l}\text { Storage } \\
\text { Area }\left(\mathrm{m}^{3}\right)\end{array}$} & \multirow{2}{*}{$\begin{array}{c}\text { Annual } \\
\text { Rainfall (mm) }\end{array}$} & \multicolumn{2}{|c|}{ Water Supply } & \multirow{2}{*}{$\begin{array}{l}\text { Additional } \\
\text { Method }\end{array}$} & \multirow{2}{*}{ References } \\
\hline & & & Irrigation & Domestic & & \\
\hline Bangladesh & $1500-6500$ & $1544^{* *}$ & $\begin{array}{c}\text { met } 43 \% \text { of water } \\
\text { demand in Tanore, } \\
\text { Rajshahi }\end{array}$ & N/A & N/A & Hasan et al. [77] \\
\hline Ethiopia & 102 & $1257^{* *}$ & $\begin{array}{l}\text { met } 45 \% \text { of seedling, } \\
\text { fruit production and } \\
50 \% \text { of livestock } \\
\text { watering in Shenkora }\end{array}$ & $\begin{array}{l}\text { meet } 5 \% \text { of water } \\
\text { demand }\end{array}$ & $\begin{array}{l}\text { Plastic lining } \\
\text { or } \\
\text { geo-membrane }\end{array}$ & Teshome et al. [67] \\
\hline Guatemala & 2500 & $1166 *$ & $\begin{array}{c}424,070.81 \mathrm{~m}^{3} \text { total } \\
\text { volume of harvested } \\
\text { water }\end{array}$ & N/A & N/A & Wu et al. [66] \\
\hline \multirow[t]{2}{*}{ India } & 23,530 & $836^{*}$ & N/A & $\begin{array}{c}23,000 \mathrm{~m}^{3} \text { meet of } \\
\text { drinking water } \\
\text { demand for the } 1632 \\
\text { population in } \\
\text { Dindigul, Tamil Nadu }\end{array}$ & Retaining wall & Farook et al. [32] \\
\hline & 1200 & $549 *$ & $\begin{array}{l}5000 \mathrm{~m}^{3} \text { total volume } \\
\text { of harvested water in } \\
\text { Satara, Maharashtra }\end{array}$ & N/A & N/A & $\begin{array}{l}\text { Ramotra and } \\
\text { Gaikwad [65] }\end{array}$ \\
\hline
\end{tabular}


Table 3. Cont

\begin{tabular}{|c|c|c|c|c|c|c|}
\hline \multirow{2}{*}{ Country } & \multirow{2}{*}{$\begin{array}{l}\text { Storage } \\
\text { Area }\left(\mathbf{m}^{3}\right)\end{array}$} & \multirow{2}{*}{$\begin{array}{c}\text { Annual } \\
\text { Rainfall (mm) }\end{array}$} & \multicolumn{2}{|c|}{ Water Supply } & \multirow{2}{*}{$\begin{array}{l}\text { Additional } \\
\text { Method }\end{array}$} & \multirow{2}{*}{ References } \\
\hline & & & Irrigation & Domestic & & \\
\hline Kenya & $30-100$ & $280-1100$ * & $\begin{array}{c}50 \mathrm{~m}^{3} \text { total volume of } \\
\text { harvested water to } \\
\text { irrigate a kitchen } \\
\text { garden in Laikipia }\end{array}$ & N/A & N/A & Ngigi et al. [69] \\
\hline
\end{tabular}

\footnotetext{
Note: ${ }^{*}$ is the annual rainfall stated in the reference. ${ }^{* *}$ is the annual rainfall compiled from officially recognized sources.
}

\subsection{Water Quality}

The quality of harvested and stored rainwater is influenced by the behavior of individual factors, such as topography, weather, and sources of pollution [78]. Harvested rainwater could be utilized as a water supply if the water quality parameter satisfies the acceptable level. Therefore, regular monitoring is needed as it has the potential for health risks due to the existence of chemical, physical and microbiological contaminants, which is presented in the case studies summarized in Table 4.

Table 4. Summary of case studies for water quality and type of treatment for the RHS and PHS.

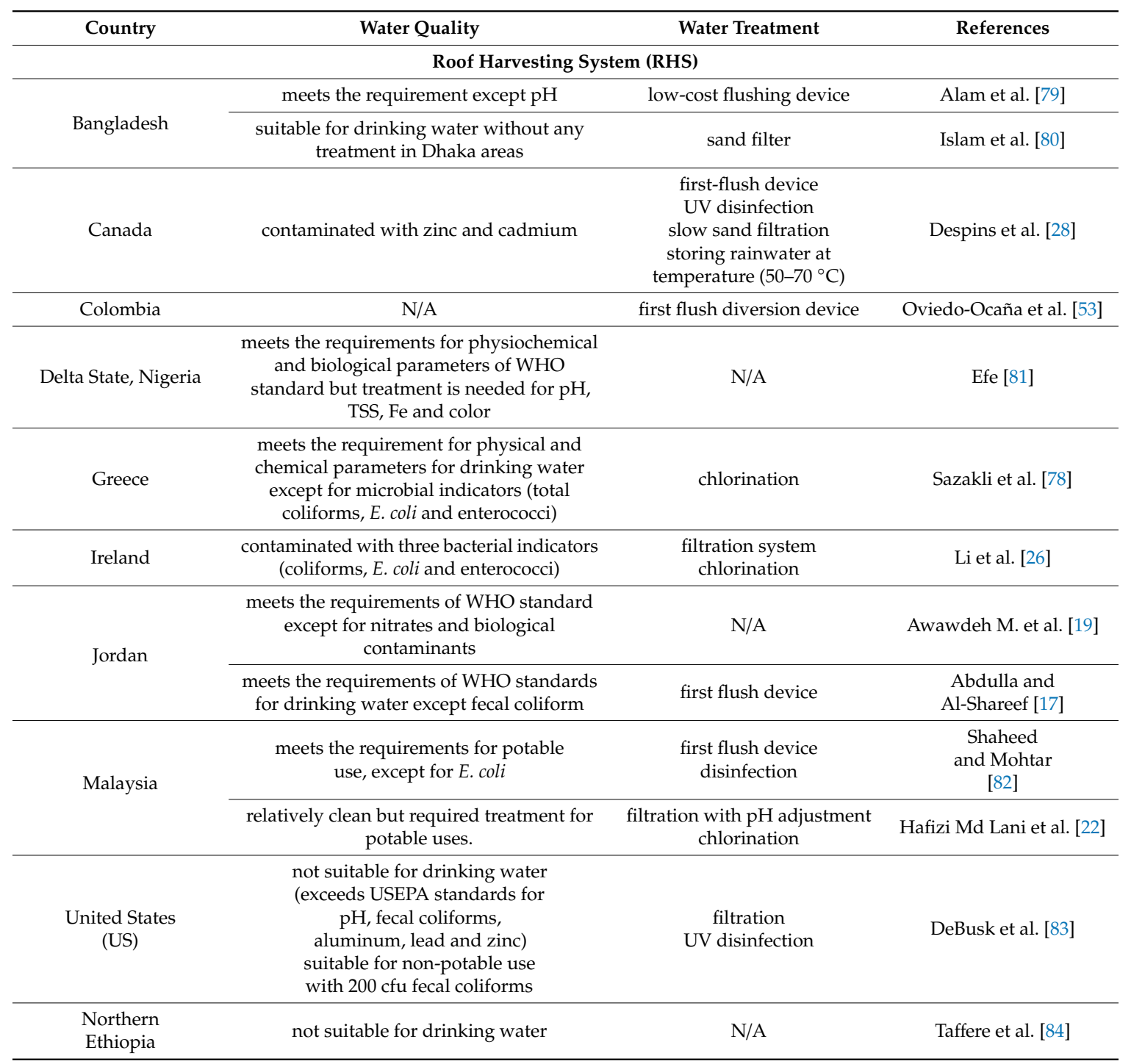


Table 4. Cont

\begin{tabular}{cccc}
\hline Palestinian & $\begin{array}{c}\text { not suitable for drinking water } \\
\text { (contaminated with coliforms and } \\
\text { heterotrophic bacteria) }\end{array}$ & $\begin{array}{c}\text { regularly cleaning } \\
\text { chlorination } \\
\text { first flush device }\end{array}$ & Daoud et al. [85] \\
\hline Portugal & N/A & $\begin{array}{c}\text { first flush device } \\
\text { filtration }\end{array}$ & Silva et al. [86] \\
\hline Zambia & $\begin{array}{c}\text { suitable for drinking water but concerned } \\
\text { with its taste and debris }\end{array}$ & N/A & Handia et al. [87] \\
\hline India & Pond Harvesting System (PHS) & Farook et al. [32] \\
\hline Kenya & $\begin{array}{c}\text { for potable uses, contaminated with excess } \\
\text { iron, turbidity and fecal coliform } \\
\text { suitable for drinking water and } \\
\text { non-potable use }\end{array}$ & chlorination & Qi et al. [88] \\
\hline South Africa & $\begin{array}{c}\text { for non-potable uses, contaminated with } \\
\text { high value of total suspended solid and } \\
E . \text { coli }\end{array}$ & filtration & RV disinfection \\
\hline
\end{tabular}

Based on Table 4, the rainwater quality of both the RHS and PHS in most of the case studies does not meet the World Health Organization (WHO) water quality standard, especially the biological parameters. The storage systems for both the RHS and PHS can be potentially contaminated by biological contaminants such as E. coli, meanwhile the rooftop catchment of the RHS may contribute to chemical contamination and the land surface catchment of the PHS may lead to physical contamination. For the RHS, major pollutants detected from the storage of harvested rainwater are microorganisms such as E. coli, coliforms and enterococci $[17,26,78,85,89]$ and fecal from birds and mammals [26]. Other contaminations were also found, especially heavy metals, such as $\mathrm{Pb}$ and $\mathrm{Zn}$ that came from the roof material and nutrient ions from the polluted atmosphere $[19,28,90]$. These levels generally exceeded the acceptable standard of water quality for non-potable use, recreational and industrial.

One of the main factors that contributes to the pollution of harvested rainwater is the improper manner of storage, such as overflow and unhygienic rainwater systems. The coliform group can be easily detected in the RHS and PHS after collection and storage, due to the potential change in the water quality within the long period of storage [91]. Microbial contamination will be the main problem if the water is used as drinking water. RHS case studies in Bangladesh, Canada, Germany, Greece, Jordan, Malaysia, Palestinian and Zambia show that the collected rainwater meets the safe drinking water standards, except for the biological parameter, which still required further treatment $[17,22,28,78,80,82,85,87]$. For PHS case studies, most of the harvested rainwater is unsafe for drinking purposes, especially in Dindigul District, India, where the harvested rainwater had exceeded the allowable standard for turbidity, iron and fecal coliform [32] and in South Africa, where the water was contaminated with high level of total suspended solid (TSS) and E. coli [44].

In United States, several guidelines by the USEPA were used to regulate the water supply standards. The Guidelines for Water are used to facilitate the developments related to water reuse, including RWHS and serve as an authoritative reference on water reuse practices [92], and the 2017 Potable Reuse Compendium is used to complement the 2012 Guidelines and discuss the current practices and methods used in potable reuse [93], while the Managing Wet Weather with Green Infrastructure Municipal Handbook-Rainwater Harvesting Policies is used to assist the local officials in implementing RWHS in their communities [16]. According to the guidelines, for potable use, the requirement should be zero for total and fecal coliforms, protozoan cysts and virus with less than one Nephelometric Turbidity Unit (NTU) of turbidity. Meanwhile, for non-potable use, there is no requirement for outdoor use but for indoor use, the minimum requirements are less than 500 colony forming units (cfu) for total coliforms and $100 \mathrm{cfu}$ for fecal coliforms per $100 \mathrm{~mL}$ [16]. From Table 3, the study by DeBusk et al. [83] showed that the harvested rainwater does not meet the USEPA drinking water standard for $\mathrm{pH}$, fecal coliforms, aluminum, lead and zinc but the amount of fecal coliform $(200 \mathrm{cfu})$ allows human contact of the harvested rainwater for non-potable use. 
Other factors that need to be considered are rainfall events and the size of storage tanks. The usage of a smaller storage system in an RHS as compared to a PHS gives the advantages of allowing the collection of all rainfall events and the pollutant being flushed away through the first flush device [94]. However, the quality of harvested rainwater will deteriorate through extreme events that occur from the worst climate change. The drought seasons will enhance the accumulation of pollutants on the roof including heavy metals from polluted air and the high capacity of accumulated water during flood events will promote mosquito breeding [95]. Under similar circumstances, the large storage system of PHS application will cause the rainwater quality to become worse due to the development of algae bloom and the reduction in dilution capacity (point sources) [96] during drought seasons as well as the rainwater that carries away harmful contaminations such as pesticides, oil and animal waste during the flash flooding. Furthermore, the downstream location of the PHS causes all the pollutants from upstream to directly flow into the pond storage within the catchment area. Although the quality of the rainwater harvested from the PHS was not as good as from RHS, the benefit of application for domestic use is still significant in terms of money saving. The cost of PHS installation can be covered through the saving from the non-potable uses, such as garden watering, toilet flushing and car washing. In addition, the adoption of a two-piped system to distribute the harvested rainwater for non-potable use in the residential area will reduce the use of treated water from the water pipe and, hence, the cost of treatment of water for potable uses can be reduced.

In order to improve the rainwater quality, the harvested rainwater must be treated for further usage, especially for potable water demand. A lot of affordable treatments have been developed and introduced for both RHS and PHS systems, such as the first flush water diverter, chlorination, pasteurization and slow sand filtration. For the RHS case study in Canada, Despins et al. [28] found that the application of the first flush method that cut the first flush of the rain event can significantly reduce the concentrations of polycyclic aromatic hydrocarbons (PAH), suspended solids, organic compounds and trace metals. Another study by Sazakli et al. [78] reported that the chlorination method can improve the microbiological quality of harvested rainwater by breaking down the microorganisms, but the reaction between the chlorine and organic matter can form undesired products at the bottom of tanks. Therefore, Li et al. [26] recommended that better treatment can be achieved by coupling chlorination and membrane filtration. In addition, slow sand filtration treatment is also commonly applied in the RHS, especially in developed countries, such as Ireland [26], Canada [28] and Australia [25], which involves graded sand layers with continuous water flow through the coarse sand at the top and finer sand at the bottom. Despite disinfection, consumers in Malaysia favored boiling the water as a prevention of bacterial contamination of harvested rainwater after which it could be considered as drinking water.

For the PHS case study in South Africa and the United Kingdom, it was stated that harvested rainwater needed a filtration treatment prior to ultraviolet (UV) disinfection due to the dependence of dosage on the UV transmittance to ensure the consistency of water quality [44]. On the other hand, for potable water demands, the harvested rainwater of the PHS needs chlorination to improve the sanitation systems [32].

\subsection{Energy Saving}

Energy consumption in RWHS normally refers to the electricity used for water storage pumping. Theoretically, RWHS consume less energy compared to conventional systems and other alternative water supply systems, such as saltwater (desalination of seawater) and greywater (reuse of water that used for bathing, laundry or washing dishes), depending on site characteristics, system configurations and economic scale [97]. For example, In Jordan, the government revealed that the conventional water supply system consumes $15 \%$ of Jordan's total electricity to pump and deliver the water, where the RHS that does not consume any energy [98]. Although RWHS consume less energy compared to conventional systems, the harvested rainwater without treatment can only satisfy non-potable uses, as treatment systems like membrane filtration consume more energy. 
Morales-Pinzon et al. [99] conducted a case study using the Plugrisost program to analyze the implementation of an RWHS in a single-family house in Aveiro, Portugal. Based on the Plugrisost model, RHS application in a single house scale tends to have lower energy consumption compared to the distribution of the conventional system [99]. However, the condition is different for high rise buildings, where more energy is consumed, with an average of the combination between energy production and water distribution network. This has led to more energy being consumed for the RHS in developed countries due to space-limited areas for development. In Australia, tap water is more important than energy consumption, because a lower cost of energy is estimated compared to the higher future prediction of the tap water price [100].

Energy consumption in the PHS is based on the elevations and distance [101]. If the PHS area is located in an area with higher elevation, the harvested rainwater can be distributed under gravitational force with little or no pumping required. However, if the harvested rainwater is distributed to a higher level than the PHS, then a pump (and energy) is needed. Similar to the distance factor, if the PHS is located far from the distributed area, more energy is needed for pumping. The size of the PHS is also another factor, where more energy is consumed for a larger pond size. A study by Mushtaq et al. [101] reported that the pumping cost increased accordingly with the increase in PHS size due to the larger amount of rainwater that is harvested.

In addition, energy saving consumption by RWHS application has also minimized carbon dioxide emissions and it is important to recognize the connection between the potable use and energy demand in the broader context of sustainable water management [16]. Kloss [16] has mentioned that if the RWHS has reduced potable water up $3785 \mathrm{~m}^{3}$, the carbon dioxide emissions will also be reduced by between 2.83 and $4.25 \mathrm{~m}^{3}$, as fossil fuels are used for power generation. A Life Cycle Assessment (LCA), case study by Ghimire et al. [102] has reported that RWHS performed better than conventional water supply for domestic water demand with energy savings and ozone depletion between $58 \%$ and $82 \%$. A similar study has also been conducted for agriculture water demand, where RWHS had better performance in ozone depletion (67\%) and energy saving $(78 \%)$ than well water irrigation. The finding was found to be similar to the case study by Leong et al. [103], where RWHS emerges as having the lowest environmental impact (least energy consumption) from the conventional water supply compared to greywater recycling and a hybrid rainwater-greywater system. Depending on the location of the storage system, using RWHS in the application of RHS and PHS has slightly reduced the usage of electricity including the energy consumption if compared to high electricity usage of the conventional water supply. Moreover, the multi benefits of a SUDS approach through a RWHS device have contributed to overall carbon sequestration which mitigates the changes brought about by increased greenhouse gas emissions leading to effective control global warming that led to the climate change.

\subsection{Economic Saving}

In some developing countries where the water tariff is high, the RWHS is considered a low-cost system that involves only the cost of storage and treatment, and it behaves as a free water source [50]. In addition, RWHS are able to generate a large amount of harvested rainwater as the decentralized system makes it less expensive than the conventional water supply systems. This is supported by Alam et al. [79], who stated that the cost of the RHS $\left(0.0007 \mathrm{USD} / \mathrm{m}^{3}\right)$ is three times cheaper than the conventional water supply system $\left(0.0018 \mathrm{USD} / \mathrm{m}^{3}\right)$ in Sylhet City, Bangladesh. In addition, the ability of RWHS to fulfill the domestic water demand reduces the dependency on the conventional water supply system and will decrease the water bills up to $50 \%$ for every month [104].

The economic benefits of RWHS can be represented through the infrastructure savings. According to Coombes et al. [105], the concern on the delay of conventional water supply headworks could be compromised with widespread installation of RWHS. Furthermore, the lower absorption rate of the roof catchment area compared to a dam's catchment has shown the efficiency of RWHS per unit volume of water. In 2003, the Australian government stated that if the water efficiency through RWHS 
application can be increased up to 3\%, the new dam that is estimated to cost USD 71.11M for 3 years could be saved at USD 711,100 per year [106]. In terms of the distribution system, where water was supplied from the conventional water system to the users, about half of the water is wasted through the direct flow of water into the drainage system without being used, which involves a cost of more than USD 26M for every year. If the same amount was used for the past 30 years, total loss of the unused water is about USD 780M. Hence, it is uneconomical compared to cost of RWHS installation (USD 336M) [107].

RWHS also provide economic benefits by reducing the damage loss due to flood as it minimizes the flood risk at the control point. For example, in the Zhong-He District, Taipei case study, Huang et al. [108] reported that the average inundated loss can be reduced up to $72 \%$ if RWHS were installed, where the cost involved without RWHS application is USD 1.04M and with RWHS is USD 0.27M. A similar case also has been found in Scotchmans Creek Catchment, Melbourne, where Jamali et al. [109] concluded that the expected annual damage is only USD 7.35M with the reduction of flood damage ranging between $18 \%$ and $31 \%$ if RWHS were applied. However, RWHS only manage to reduce the damage loss for small to medium floods, not for the larger floods due to inability of RWHS to eliminate the flood entirely. Furthermore, the construction cost for stormwater drainage will be saved through the application of RWHS, as revealed by Coombes et al. [38] in Newcastle, Australia, where USD 25,900 or $1 \%$ of the cost was saved with USD 959 per dwelling in construction cost.

Benefit-Cost Ratio (BCR) is another standard often used to evaluate the economic feasibility of a project. The higher the ratio (more than one), the more economically feasible the project. The BCR compares the benefits of reduced potable water use with the costs of implementing and maintaining RWHS. Generally, the BCR of RWHS is influenced by the tank size, location and water use but it is impossible to achieve a higher ratio if the water price is lower. For instance, a case study in Australia showed that the BCR obtained is too small and it is impossible to achieve a ratio greater than one with the current water price of $1.43 \mathrm{USD} / \mathrm{m}^{3}$ [54]. Another study in Korea has reported that the estimation of BCR was less than 0.2 due to the conventional water supply system being very inexpensive [35]. A similar situation occurred in Malaysia, where the water tariff is considered lower $\left(0.39 \mathrm{USD} / \mathrm{m}^{3}\right)$ compared to neighboring countries, such as Singapore $\left(2.39 \mathrm{USD} / \mathrm{m}^{3}\right)$ and Indonesia $\left(0.51 \mathrm{USD} / \mathrm{m}^{3}\right)$. The cost of RWHS installation is estimated to be between USD 400 and USD 3000, which is expensive especially for people in the low income category [22]. The costly installation of RWHS has caused longer payback times, usually in years and it is uneconomical to implement, as the installation cost far exceeds the benefits of water, energy and carbon saved.

The potential benefits of the PHS in irrigation can be measured through increases in yield and cropped area by comparing a situation where there is no pond water available, to a situation with a pond. In China, a case study was conducted to compare the BCR for various size of PHS, including large, medium and small, and the result showed that all sizes of ponds are profit-making with healthy internal rates of return, positive net present values and BCRs larger than one. For larger ponds, the BCR still exceeds one, even with family labor cost included [101]. In another case study in Ethiopia, it was reported that the investment of $180 \mathrm{~m}^{3}$ unlined and lined PHS can be paid in less than 3 and 5 years, respectively, and the benefit-cost ratio is equal to or exceeds one [31]. In the meantime, it was also stated that a concrete PHS with $80 \mathrm{~m}^{3}$ of capacity could serve a similar irrigation demand as an unlined PHS with a $180 \mathrm{~m}^{3}$ capacity, but the concrete PHS caused a longer payback period (9 years), as it involved higher investment costs.

PHS application can also increase the farmers' income with supplementary annual harvest and allow an annual planting season throughout the dry seasons [110]. For example, farmers in India experienced a substantial increase in income from USD 109.97/year to USD 216.36/year [111] and in Bangladesh, the cost of irrigation can save about USD 1344.26M [112]. Besides boosting the farmers' income, PHS application also assisted the cost benefit during flood events. By capturing almost all the runoff, the recovery cost due to flooding was saved through minimal infrastructure damage and the saving of many lives. Currently, due to less PHS application, flooding causes more losses. For instance, 
in part of north and eastern Malaysia, flood disasters have caused severe damage and loss of property which has exceeded USD 300M [113].

In summary, for RHS application, it is only economical to implement it in countries with high water tariffs as RWHS consume less energy and are considered cheaper than the conventional water supply system. However, in countries with low water tariffs, the cost of installation has increased the payback period and the system become less worthy to implement. Unlike the RHS, the PHS is suitable to be implemented in the countries regardless of high or low water tariffs as it gives high benefit returns and short payback periods, especially the large pond size. However, this estimation is only applicable for the PHS that is used for irrigation and, therefore, further BCR study on PHS application for domestic water usage is needed.

\section{Challenges and Way Forward}

This section will discuss on the challenges as well as the way forward for RWHS application.

\subsection{Challenges}

In some regions that lack facilities for conventional water treatment, the harvested rainwater is considered safe and clean for health purposes [114]. The sustainable source of harvested rainwater can supplement the drinking water and food security, which helps to decrease the health problem and provide better life quality for those communities. For PHS application, it helps improve the agriculture sector, which spontaneously offers a lot of job opportunities for the villagers, increases the household income and provides children with a better chance of education [110].

Even though RWHS provide a lot of benefits, a lack of awareness by the users about RWHS still exists. In Uganda, the RWHS was mismanaged due to insufficient information caused by a poor road problem, shortage of electricity and limited access to internet [115]. Therefore, this has created gap of knowledge among the villagers, especially about the life cycle expenditure and advantages of RWHS. The knowledge gap has caused the people to tend to look forward for public support due to their unwillingness to pay for the operating cost. In Malaysia, the acceptance of RWHS is still unsatisfactory, despite various initiatives taken by the government to promote RWHS. One of the main reasons for poor acceptance is due to the low water tariff, where the price is between USD 0.21 and USD 0.70 [22]. In addition, being blessed with abundant rainfall has caused the public not to be concerned about RWHS as a water saving device, which is proven by the high rate of domestic water consumption (ranging 209 to 228 litres per capita per day, lcd) compared to the WHO recommended target $(165 \mathrm{lcd})$.

Another factor of low RWHS application is a lack of interest by the developer due to cost factors and unfamiliarity with the system. For instance, in Malaysia, cost factors have acted as the main barrier in implementing RWHS, due to a lack of support by the developers as well as a lack of financial incentives and subsidies by the government. Most of the developers refuse to cover the $1 \%$ cost of RWHS installation from the total cost housing development [116]. On the other hand, the unfamiliarity with RWHS among the developers in Spain has caused misleading information to be given to the buyer about this system, that the RWHS do not give an added value to a new residential building [89].

\subsection{Way Forward}

Nowadays, Sustainable Development Goals (SDGs) have become a popular concept adapted by most of the countries in tackling climate change and working to preserve the oceans and forests. The SGDs concept that was adopted by the United Nations (UN) aimed to improve people's lives and to protect the planet for future generations including by economic development, social inclusion, and sustainable environmental management [117]. With the application of RWHS, SDGs especially SDG 13 that urge the taking of urgent action to combat climate change and its impacts and SDG 6 that calls for clean water and sanitation for all people can be achieved with the benefits gained from the environment, economic and social aspects. Therefore, cooperation and support from various 
parties/stakeholders are crucial to ensure the successful application of this sustainable system towards the goals of the $2030 \mathrm{New}$ Urban Agenda for the availability and sustainable management of water.

First and foremost, the government need to break down the barrier of RWHS among the society by associating with the mass media in promoting and increasing the popularity of RWHS as well as introducing it from an early stage of school subjects [71]. For example, in Malaysia, the RWHS information could be inserted into a subject named Kemahiran Hidup (Living Skills) or Geography in both primary and secondary school [118]. Meantime, in Australia, a school project on RWHS has been started in certain state governments as well as a rebate up to USD 2500 was given for rainwater harvesting tank installation.

Next, in order to further reduce the cost of RWHS installation, demand from the users needs to be increased to encourage competition among the suppliers. It involves initiative of the individual to adopt it into their own house, especially for the existing residential area. Therefore, in the beginning stage, the government's support by providing subsidies and tax rebates to the public for RWHS implementation is required [118]. Several countries have introduced subsidies to support the success of RWHS especially during the initial stages of installation. For example, the Australian government provides subsidies to residents who have installed RWHS through the Home Water Wise Rebate scheme [119] and the German government subsidized 1/3 of total cost installation or up to USD 2170.48 [120]. Besides subsidies, the tax rebate is another economic incentive which is offered to homeowners or public members who decided to install RWHS, and it is also given to manufacturers and suppliers of RWHS materials or equipment. This method was successfully implemented in certain regions of India, with rebates of $6 \%$ on property tax by the Indore Municipal Corporation (IMC) [118]. Those incentives and supports from the government will act as the first move to encourage the RWHS implementation among the public.

From previous studies, the water tariff is one of the major barriers for RWHS application. By increasing the water tariff, this could change the water usage behavior of society and save more water through RWHS application. For instance, studies in Sydney and Spain have stated that the price should increase from USD $1.40 / \mathrm{m}^{3}$ to USD $1.57 / \mathrm{m}^{3}$ and from USD $1.52 / \mathrm{m}^{3}$ up to USD $4.35 / \mathrm{m}^{3}$, respectively [54,99]. Another study in South Korea also stated that the current water price should be increased five-fold [35] especially in developing countries such as Malaysia.

Meanwhile, the restriction of pipe water usage especially during critical periods will also encourage the application of RWHS. Such a policy has been adopted in Australia, where the water usage was restricted for non-potable use, such as watering gardens and washing cars at individual property during dry seasons [121]. Another country, Brazil, also implemented this method, where the water tariff will be increased to USD $0.079 / \mathrm{m}^{3}$, if the water usage is higher than $10 \mathrm{~m}^{3} / \mathrm{month}$ for local water and sewage utility [122]. In this scenario, a two-piped distribution system which divides the water usage into potable and non-potable use from different sources could reduce the dependency on pipe water from the conventional water supply. Such a practice has been recommended by World Health Organization (WHO) [123] under dual supply systems, where each supply system carried mains water that has been treated and secondary sources (in this context known as the harvested rainwater). Dual supply systems should be practiced separately as it does not allowed reconnection between secondary sources with the main water. The purpose is to prevent the contamination that be might come from secondary sources (which allow the foreign substances) to enter the mains water that will be used to supply the drinking water as well as for human consumption, such as bathing, food preparation and washing clothes. In addition, the installation of backflow prevention and cross-connection control are necessary, where unclean water from secondary sources can totally be avoided and used mainly for the fire protection, garden watering and irrigation. The prevention should be done from the sources, where storage tanks that combine both mains water and secondary sources, need to be installed with double partition walls to separate those two water supplies. In fact, such a practice has been well implemented in developed countries such as United Kingdom and Australia as it has qualified guidelines that can be followed, but not for the developing countries like Malaysia, 
where the guidelines are still focused on a single supply system. Therefore, it is necessary to update the guidelines as this practice is well recommended, especially for PHS application in newly developed residential areas that involve a large community.

Other than encouraging RWHS implementation in a conventional way, enhancement of this system through a smart optimization system was also recommended using Internet of Things (IoT). IoT is one of the advanced communication systems that connects the internet with sensors and working devices, which link physical and virtual objects with devices that have the capabilities in capturing data and communication [124]. For instance, in terms of water quality, automatic RWHS using micro-controllers possess $\mathrm{pH}$ sensors, conductivity sensors and turbidity sensors, where the prototype hardware model of RWHS uses the filtration method, sending the data collected through IoT [125]. Through this system, pure water can be obtained from the harvested rainwater and it is suitable for household consumption, gardening as well as electrical and industrial applications. In terms of water quantity, the rainwater sensor and water level sensor are automatically activated once rain is detected and closed when it has achieved the optimum water level [126]. Another smart feature of IoT called the Smart Rain Barrel (SRB), used IoT and a rain barrel that are connected to each other to function as real-time monitored and real-time controlled systems. A study from a university campus in Innsbruck, Austria showed that by using SRB, all the flow including inflow and outflow was measured in real time as well as the level of water that was filled for different LIDs and the central sewer system [127].

Before the RWHS implementation, the requirement to evaluate the potential of RWHS in terms of water quantity, especially runoff reduction, can also be upgraded by using the Technique for Order Preference by Similarity to Ideal Solution (TOPSIS) and the Rough Set method. This method was introduced by Palermo et al. [128], where TOPSIS compared algorithms and analyzed the performance alternatives, while the Rough Set method acts as a machine that learns to optimize the RWHS. The outcome is to improve the previous knowledge in this field and introduce additional methods to identify the optimal rainwater reuse that can save water and reduce the runoff discharged to the sewer system. RWHS are definitely a beneficial way forward able to contribute towards enhanced water security and at the same time facilitate sustainable growth for society and eventually replace all unsustainable drainage.

\section{Conclusions}

With rising urbanization and population explosion as well as unpredictable climate change, water security can be achieved by practicing one of the SUDS techniques, which is RWHS. The use of RWHS to fulfill the domestic water demand has been clearly recognized through RHS application, but PHS application is still in doubt, even though the only differences between these systems are the scale and the use of the conveyance system. Therefore, in this study, by using RHS application as the benchmark, the exploration of PHS application in achieving the SUDS elements was reviewed considering water quantity and quality, with additional elements of sustainability such as energy and economic savings.

It was concluded that a strategy of SUDS for climate change adaption can be achieved by using RWHS through RHS and PHS application. Firstly, both the RHS and PHS have delivered the elements of minimizing the water quantity of flood and reducing peak flow, and PHS application gives an added value by recharging into the groundwater. Furthermore, in water supply, PHS application also showed more benefits compared to RHS application due to its larger scale that is able to collect and save more rainwater. Secondly, for water quality, studies have found contamination of biological contaminants in rainwater collected for both RHS and PHS application, rendering the rainwater collected only for non-potable use. This has indicated that further research is needed to ensure the stored harvested rainwater satisfies the drinking water quality. The use of RWHS is capable of saving energy consumption and helps to reduce carbon dioxide emissions. The capability depends on the location of storage system, where RHS on high-rise buildings and PHS at lower levels and far from the area of consumption need higher energy consumption. Meanwhile in the economic 
domain, RHS application only gives economic benefit for countries with high water tariffs, while PHS application benefited all, especially in irrigation and providing additional income to the farmers.

This study suggested that PHS application used for irrigation purposes, is great to replace or complement RHS application for fulfilling domestic water demands especially in developing countries with humid tropical climates as these countries have abundant rainfall and unused land. With advantages that reduce dependency on conventional pipe water, its large pond size gives high benefit returns and short payback periods. However, the main challenge that needs to be overcome is lack of users' awareness, which has restrained implementation, as the introduction of RWHS has been focused on RHS application, previously. Hence, desperate initiative from the government is vital, with earlier introduction to the subject at school and mass media participation, supplemented with subsidies as well as tax rebates and increases in the water tariff at the same time. Additional to that, the introduction of dual supply systems can reduce the concerns of the water quality, as the harvested rainwater will only be used on non-potable demands.

Author Contributions: Conceptualization, H.A.Z. and H.W.G., C.K.C.; Writing-Original Draft Preparation, H.A.Z.; Writing-Review and Editing, H.A.Z., H.W.G., C.K.C. and N.W.C.; Project Administration, H.W.G.; Funding Acquisition, N.A.Z. All authors have read and agreed to the published version of the manuscript.

Funding: This research was funded by Ministry of Education Malaysia under the Malaysia Research University Network (MRUN) collaborative research program, with the project title: Sustainable Water Resources Management Solutions to Overcome National Water Security Issues (Project No. 203/PREDAC/6720016).

Conflicts of Interest: The authors declare no conflict of interest.

\section{References}

1. Jaramillo, P.; Nazemi, A. Assessing urban water security under changing climate: Challenges and ways forward. Sustain. Cities Soc. 2018, 41, 907-918.

2. Allan, C.; Xia, J.; Pahl-Wostl, C. Climate change and water security: Challenges for adaptive water management. Curr. Opin. Environ. Sustain. 2013, 5, 625-632.

3. Tan, M.L.; Ficklin, D.L.; Ibrahim, A.L.; Yusop, Z. Impacts and uncertainties of climate change on streamflow of the Johor River Basin, Malaysia using a CMIP5 General Circulation Model ensemble. J. Water Clim. Chang. 2014, 5, 676-695.

4. Tan, M.L.; Ibrahim, A.L.; Cracknell, A.P.; Yusop, Z. Changes in precipitation extremes over the Kelantan River Basin, Malaysia. Int. J. Climatol. 2017, 37, 3780-3797.

5. Tan, M.L.; Samat, N.; Chan, N.W.; Lee, A.J.; Li, C. Analysis of precipitation and temperature extremes over the Muda River Basin, Malaysia. Water 2019, 11, 283.

6. Chocat, B.; Ashley, R.; Marsalek, J.; Matos, M.; Rauch, W.; Schilling, W.; Urbonas, B. Toward the sustainable management of urban storm-water. Indoor Built Environ. 2007, 16, 273-285.

7. Prince George's County (Md.); Division, P. Low-Impact Development: An Integrated Design Approach; Department of Environmental Resource, Programs and Planning Division: Peppercorn Place Largo, MD, USA, 1999.

8. Martin, P.; Turner, B.; Waddington, K.; Pratt, C.; Campbell, N.; Payne, J.; Reed, B. Sustainable Urban Drainage Systems: Design Manual for Scotland and Northern Ireland; C521; CIRIA: London, UK, 2000.

9. Schueler, T.R. Controlling Urban Runoff: A Practical Manual for Planning and Designing Urban BMPs; Water Resources Publications: Washington, DC, USA, 1987.

10. DID, E. Urban Stormwater Management Manual for Malaysia; Department of Irrigation and Drainage Malaysia: Kuala Lumpur, Malaysia, 2012.

11. Sharma, A.; Gray, S.; Diaper, C.; Liston, P.; Howe, C. Assessing integrated water management options for urban developments-Canberra case study. Urban Water J. 2008, 5, 147-159.

12. Willems, P.; Arnbjerg-Nielsen, K.; Olsson, J.; Nguyen, V. Climate change impact assessment on urban rainfall extremes and urban drainage: Methods and shortcomings. Atmos. Res. 2012, 103, 106-118.

13. Ashley, R.; Garvin, S.; Pasche, E.; Vassilopoulos, A.; Zevenbergen, C. Advances in Urban Flood Management; CRC Press: Boca Raton, FL, USA, 2007.

14. Elliott, A.; Trowsdale, S.A. A review of models for low impact urban stormwater drainage. Environ. Model. Softw. 2007, 22, 394-405. 
15. Torres, M.N.; Fontecha, J.E.; Zhu, Z.; Walteros, J.L.; Rodríguez, J.P. A participatory approach based on stochastic optimization for the spatial allocation of Sustainable Urban Drainage Systems for rainwater harvesting. Environ. Model. Softw. 2020, 123, 104532.

16. Kloss, C. Managing Wet Weather with Green Infrastructure Municipal Handbook: Rainwater Harvesting Policies; US Environmental Protection Agency: Washington, DC, USA, 2008.

17. Abdulla, F.A.; Al-Shareef, A. Roof rainwater harvesting systems for household water supply in Jordan. Desalination 2009, 243, 195-207.

18. Chan, N.W.; Zakaria, N.; Ab Ghani, A.; Nitivattananon, V. Incorporating rainfall harvesting mechanisms into building designs for water resources management: Examples from Malaysia. In Proceedings of the Regional Conference on Urban Water and Sanitation in Southeast Asian Cities, Vientiane, Laos, 22-24 November 2006; SEA-UEMA: Pathumthani, Thailand, 2006.

19. Awawdeh, M.; Al-Shraideh, S.; Al-Qudah, K.; Jaradat, R. Rainwater harvesting assessment for a small size urban area in Jordan. Int. J. Water Resour. Environ. Eng. 2012, 4, 415-422.

20. Chan, N.W. Holistic Urban Water Management Integrating Rainfall Harvesting, Water Conservation and Sustainable Drainage Systems in Universiti Sains Malaysia. In Proceedings of the 5th International Conference on Advances in Environment Research (ICAER 2019), Singapore, 13-15 August 2019.

21. Suhaila, J.; Deni, S.M.; Zin, W.Z.W.; Jemain, A.A. Trends in peninsular Malaysia rainfall data during the southwest monsoon and northeast monsoon seasons: 1975-2004. Sains Malays. 2010, 39, 533-542.

22. Hafizi Md Lani, N.; Yusop, Z.; Syafiuddin, A. A review of rainwater harvesting in Malaysia: Prospects and challenges. Water 2018, 10, 506.

23. Farreny, R.; Morales-Pinzón, T.; Guisasola, A.; Tayà, C.; Rieradevall, J.; Gabarrell, X. Roof selection for rainwater harvesting: Quantity and quality assessments in Spain. Water Res. 2011, 45, 3245-3254.

24. Liuzzo, L.; Notaro, V.; Freni, G. A reliability analysis of a rainfall harvesting system in southern Italy. Water 2016, 8, 18.

25. Cook, S.; Sharma, A.; Chong, M. Performance analysis of a communal residential rainwater system for potable supply: A case study in Brisbane, Australia. Water Resour. Manag. 2013, 27, 4865-4876.

26. Li, Z.; Boyle, F.; Reynolds, A. Rainwater harvesting and greywater treatment systems for domestic application in Ireland. Desalination 2010, 260, 1-8.

27. Hatibu, N.; Mutabazi, K.; Senkondo, E.; Msangi, A. Economics of rainwater harvesting for crop enterprises in semi-arid areas of East Africa. Agric. Water Manag. 2006, 80, 74-86.

28. Despins, C.; Farahbakhsh, K.; Leidl, C. Assessment of rainwater quality from rainwater harvesting systems in Ontario, Canada. J. Water Supply Res. Technol. AQUA 2009, 58, 117-134.

29. Chan, N.W. The N-Park Negalitres Project: A pilot water-saving initiative using green technology and changing water use behaviour. Water Green Econ. 2012, 1, 75-90.

30. Oweis, T.; Hachum, A. Water harvesting and supplemental irrigation for improved water productivity of dry farming systems in West Asia and North Africa. Agric. Water Manag. 2006, 80, 57-73. [CrossRef]

31. Moges, G.; Hengsdijk, H.; Jansen, H. Review and quantitative assessment of ex situ household rainwater harvesting systems in Ethiopia. Agric. Water Manag. 2011, 98, 1215-1227. [CrossRef]

32. Farook, C.M.; Mariappan, P.; Neelakantan, T. Hydrology and Water Quality of Traditional Rainwater Harvesting Drinking Water Pond at Samuthirapatty Village, Dindigul District, Tamil Nadu. ARPN J. Eng. Appl. Sci. 2006, 9, 2551-2558.

33. Zhang, X.; Hu, M.; Chen, G.; Xu, Y. Urban rainwater utilization and its role in mitigating urban waterlogging problems-A case study in Nanjing, China. Water Resour. Manag. 2012, 26, 3757-3766. [CrossRef]

34. Freni, G.; Liuzzo, L. Effectiveness of rainwater harvesting systems for flood reduction in residential urban areas. Water 2019, 11, 1389. [CrossRef]

35. Kim, K.; Yoo, C. Hydrological modeling and evaluation of rainwater harvesting facilities: Case study on several rainwater harvesting facilities in Korea. J. Hydrol. Eng. 2009, 14, 545-561. [CrossRef]

36. Fisher-Jeffes, L.; Armitage, N.; Carden, K. The viability of domestic rainwater harvesting in the residential areas of the Liesbeek River Catchment, Cape Town. Water SA 2017, 43, 81-90. [CrossRef]

37. Basinger, M.; Montalto, F.; Lall, U. A rainwater harvesting system reliability model based on nonparametric stochastic rainfall generator. J. Hydrol. 2010, 392, 105-118. [CrossRef]

38. Coombes, P.J.; Argue, J.R.; Kuczera, G. Figtree Place: A case study in water sensitive urban development (WSUD). Urban Water 2000, 1, 335-343. [CrossRef] 
39. Palla, A.; Gnecco, I.; La Barbera, P. The impact of domestic rainwater harvesting systems in storm water runoff mitigation at the urban block scale. J. Environ. Manag. 2017, 191, 297-305. [CrossRef]

40. Deitch, M.J.; Feirer, S.T. Cumulative impacts of residential rainwater harvesting on stormwater discharge through a peri-urban drainage network. J. Environ. Manag. 2019, 243, 127-136. [CrossRef]

41. Petrucci, G.; Deroubaix, J.-F.; De Gouvello, B.; Deutsch, J.-C.; Bompard, P.; Tassin, B. Rainwater harvesting to control stormwater runoff in suburban areas. An experimental case-study. Urban Water J. 2012, 9, 45-55. [CrossRef]

42. Zheng, H.; Gao, J.; Xie, G.; Jin, Y.; Zhang, B. Identifying important ecological areas for potential rainwater harvesting in the semi-arid area of Chifeng, China. PLOS ONE 2018, 13, e0201132. [CrossRef] [PubMed]

43. Ibrahim, G.R.F.; Rasul, A.; Ali Hamid, A.; Ali, Z.F.; Dewana, A.A. Suitable site selection for rainwater harvesting and storage case study using Dohuk Governorate. Water 2019, 11, 864. [CrossRef]

44. Rohrer, A.R.; Armitage, N.P. Improving the viability of stormwater harvesting through rudimentary real time control. Water 2017, 9, 371.

45. Londra, P.; Theocharis, A.; Baltas, E.; Tsihrintzis, V. Optimal sizing of rainwater harvesting tanks for domestic use in Greece. Water Resour. Manag. 2015, 29, 4357-4377. [CrossRef]

46. Słyś, D.; Stec, A. Centralized or Decentralized Rainwater Harvesting Systems: A Case Study. Resources 2020, 9, 5. [CrossRef]

47. Lin, C.-C.; Liou, K.-Y.; Lee, M.; Chiueh, P.-T. Impacts of urban water consumption under climate change: An adaptation measure of rainwater harvesting system. J. Hydrol. 2019, 572, 160-168. [CrossRef]

48. Bashar, M.Z.I.; Karim, M.R.; Imteaz, M.A. Reliability and economic analysis of urban rainwater harvesting: A comparative study within six major cities of Bangladesh. Resour. Conserv. Recycl. 2018, 133, 146-154. [CrossRef]

49. Hashim, H.; Hudzori, A.; Yusop, Z.; Ho, W. Simulation based programming for optimization of large-scale rainwater harvesting system: Malaysia case study. Resour. Conserv. Recycl. 2013, 80, 1-9. [CrossRef]

50. Aladenola, O.O.; Adeboye, O.B. Assessing the potential for rainwater harvesting. Water Resour. Manag. 2010, 24, 2129-2137. [CrossRef]

51. Ghisi, E.; Bressan, D.L.; Martini, M. Rainwater tank capacity and potential for potable water savings by using rainwater in the residential sector of southeastern Brazil. Build. Environ. 2007, 42, 1654-1666. [CrossRef]

52. Kuntz Maykot, J.; Ghisi, E. Assessment of A Rainwater Harvesting System in A Multi-Storey Residential Building in Brazil. Water 2020, 12, 546. [CrossRef]

53. Oviedo-Ocaña, E.R.; Dominguez, I.; Ward, S.; Rivera-Sanchez, M.L.; Zaraza-Peña, J.M. Financial feasibility of end-user designed rainwater harvesting and greywater reuse systems for high water use households. Environ. Sci. Pollut. Res. 2018, 25, 19200-19216. [CrossRef]

54. Hajani, E.; Rahman, A. Reliability and cost analysis of a rainwater harvesting system in peri-urban regions of Greater Sydney, Australia. Water 2014, 6, 945-960. [CrossRef]

55. Alim, M.A.; Rahman, A.; Tao, Z.; Samali, B.; Khan, M.M.; Shirin, S. Feasibility analysis of a small-scale rainwater harvesting system for drinking water production at Werrington, New South Wales, Australia. J. Clean. Prod. 2020, 270, 122437. [CrossRef]

56. Vialle, C.; Sablayrolles, C.; Lovera, M.; Huau, M.-C.; Montréjaud-Vignoles, M. Modelling of a roof runoff harvesting system: The use of rainwater for toilet flushing. Water Sci. Technol. Water Supply 2011, 11, 151-158. [CrossRef]

57. Ghimire, S.R.; Johnston, J.M.; Ingwersen, W.W.; Sojka, S. Life cycle assessment of a commercial rainwater harvesting system compared with a municipal water supply system. J. Clean. Prod. 2017, 151, 74-86. [CrossRef]

58. Melville-Shreeve, P.; Ward, S.; Butler, D. Rainwater harvesting typologies for UK houses: A multi criteria analysis of system configurations. Water 2016, 8, 129. [CrossRef]

59. Akter, A.; Ahmed, S. Potentiality of rainwater harvesting for an urban community in Bangladesh. J. Hydrol. 2015, 528, 84-93. [CrossRef]

60. Karim, M.R. Assessment of rainwater harvesting for drinking water supply in Bangladesh. Water Sci. Technol. Water Supply 2010, 10, 243-249. [CrossRef]

61. Traboulsi, H.; Traboulsi, M. Rooftop level rainwater harvesting system. Appl. Water Sci. 2017, 7, 769-775. [CrossRef] 
62. Nnaji, C.C.; Mama, N.C. Preliminary assessment of rainwater harvesting potential in Nigeria: Focus on flood mitigation and domestic water supply. Water Resour. Manag. 2014, 28, 1907-1920. [CrossRef]

63. Vialle, C.; Sablayrolles, C.; Lovera, M.; Jacob, S.; Huau, M.-C.; Montrejaud-Vignoles, M. Monitoring of water quality from roof runoff: Interpretation using multivariate analysis. Water Res. 2011, 45, 3765-3775. [CrossRef]

64. Karim, M.R.; Bashar, M.Z.I.; Imteaz, M.A. Reliability and economic analysis of urban rainwater harvesting in a megacity in Bangladesh. Resour. Conserv. Recycl. 2015, 104, 61-67. [CrossRef]

65. Ramotra, K.; Gaikwad, V. Surface rainwater harvesting potentiality and impact of Dhaval micro-watershed in Satara district, Maharashtra, India. J. Environ. Earth Sci. ISSN 2012, 2, 2224-3216.

66. Wu, R.-S.; Molina, G.L.L.; Hussain, F. Optimal sites identification for rainwater harvesting in northeastern guatemala by analytical hierarchy process. Water Resour. Manag. 2018, 32, 4139-4153. [CrossRef]

67. Teshome, A.; Adgo, E.; Mati, B. Impact of water harvesting ponds on household incomes and rural livelihoods in Minjar Shenkora district of Ethiopia. Ecohydrol. Hydrobiol. 2010, 10, 315-322. [CrossRef]

68. Panigrahi, B.; Panda, S.N.; Mal, B.C. Rainwater conservation and recycling by optimal size on-farm reservoir. Resour. Conserv. Recycl. 2007, 50, 459-474. [CrossRef]

69. Ngigi, S.N.; Savenije, H.H.; Thome, J.N.; Rockström, J.; de Vries, F.P. Agro-hydrological evaluation of on-farm rainwater storage systems for supplemental irrigation in Laikipia district, Kenya. Agric. Water Manag. 2005, 73, 21-41. [CrossRef]

70. Pandey, P.K.; Soupir, M.L.; Singh, V.P.; Panda, S.N.; Pandey, V. Modeling rainwater storage in distributed reservoir systems in humid subtropical and tropical Savannah Regions. Water Resour. Manag. 2011, 25, 3091. [CrossRef]

71. Lee, K.E.; Mokhtar, M.; Hanafiah, M.M.; Halim, A.A.; Badusah, J. Rainwater harvesting as an alternative water resource in Malaysia: Potential, policies and development. J. Clean. Prod. 2016, 126, 218-222. [CrossRef]

72. Cohen-Shacham, E.; Walters, G.; Janzen, C.; Maginnis, S. Nature-Based Solutions to Address Global Societal Challenges; IUCN: Gland, Switzerland, 2016; Volume 97.

73. Oral, H.V.; Carvalho, P.; Gajewska, M.; Ursino, N.; Masi, F.; Hullebusch, E.D.v.; Kazak, J.K.; Exposito, A.; Cipolletta, G.; Andersen, T.R. A review of nature-based solutions for urban water management in European circular cities: A critical assessment based on case studies and literature. Blue Green Syst. 2020, 2, 112-136. [CrossRef]

74. Masi, F.; Rizzo, A.; Bresciani, R.; Conte, G. Constructed wetlands for combined sewer overflow treatment: Ecosystem services at Gorla Maggiore, Italy. Ecol. Eng. 2017, 98, 427-438. [CrossRef]

75. Zakaria, N.A.; Ab Ghani, A.; Abdullah, R.; Sidek, L.M.; Ainan, A. Bio-ecological drainage system (BIOECODS) for water quantity and quality control. Int. J. River Basin Manag. 2003, 1, 237-251. [CrossRef]

76. Maryanti, M.; Khadijah, H.; Uzair, A.M.; Ghazali, M.M.M. The urban green space provision using the standards approach: Issues and challenges of its implementation in Malaysia. Wit Trans. Ecol. Environ. 2017, 210, 369-379.

77. Hasan, M.R.; Nuruzzaman, M.; Mamun, A.A. Contribution of rainwater to the irrigation requirement for paddy cultivation at Tanore Upazila in Rajshahi, Bangladesh. AirSoil Water Res. 2019, 12, 1178622119837544. [CrossRef]

78. Sazakli, E.; Alexopoulos, A.; Leotsinidis, M. Rainwater harvesting, quality assessment and utilization in Kefalonia Island, Greece. Water Res. 2007, 41, 2039-2047. [CrossRef]

79. Alam, R.; Munna, G.; Chowdhury, M.; Sarkar, M.; Ahmed, M.; Rahman, M.; Jesmin, F.; Toimoor, M. Feasibility study of rainwater harvesting system in Sylhet City. Environ. Monit. Assess. 2012, 184, 573-580. [CrossRef]

80. Islam, M.M.; Chou, F.-F.; Kabir, M.; Liaw, C.-H. Rainwater: A potential alternative source for scarce safe drinking and arsenic contaminated water in Bangladesh. Water Resour. Manag. 2010, 24, 3987-4008. [CrossRef]

81. Efe, S. Quality of rainwater harvesting for rural communities of Delta State, Nigeria. Environmentalist 2006, 26, 175-181. [CrossRef]

82. Shaheed, R.; Mohtar, W.H.M.W. Potential of using rainwater for potable purpose in Malaysia with varying antecedent dry intervals. J. Teknol 2014, 72, 57-61. [CrossRef]

83. DeBusk, K.M.; Hunt, W.F.; Osmond, D.L.; Cope, W.G. Water Quality of Rooftop Runoff: Implications for Residential Water Harvesting Systems; North Carolina Cooperative Extension: Charlotte, NC, USA, 2009. 
84. Taffere, G.R.; Beyene, A.; Vuai, S.A.; Gasana, J.; Seleshi, Y. Characterization of atmospheric bulk deposition: Implications on the quality of rainwater harvesting systems in the semi-arid City of Mekelle, Northern Ethiopia. Environ. Process. 2016, 3, 247-261. [CrossRef]

85. Daoud, A.; Swaileh, K.; Hussein, R.M.; Matani, M. Quality assessment of roof-harvested rainwater in the West Bank, Palestinian Authority. J. Water Health 2011, 9, 525-533. [CrossRef]

86. Silva, C.M.; Sousa, V.; Carvalho, N.V. Evaluation of rainwater harvesting in Portugal: Application to single-family residences. Resour. Conserv. Recycl. 2015, 94, 21-34. [CrossRef]

87. Handia, L.; Tembo, J.M.; Mwiindwa, C. Potential of rainwater harvesting in urban Zambia. Phys. Chem. EarthParts A/B/C 2003, 28, 893-896. [CrossRef]

88. Qi, Q.; Marwa, J.; Mwamila, T.B.; Gwenzi, W.; Noubactep, C. Making Rainwater Harvesting a Key Solution for Water Management: The Universality of the Kilimanjaro Concept. Sustainability 2019, 11, 5606. [CrossRef]

89. Domènech, L.; Saurí, D. A comparative appraisal of the use of rainwater harvesting in single and multi-family buildings of the Metropolitan Area of Barcelona (Spain): Social experience, drinking water savings and economic costs. J. Clean. Prod. 2011, 19, 598-608. [CrossRef]

90. GhaffarianHoseini, A.; Tookey, J.; GhaffarianHoseini, A.; Yusoff, S.M.; Hassan, N.B. State of the art of rainwater harvesting systems towards promoting green built environments: A review. Desalin. Water Treat. 2016, 57, 95-104. [CrossRef]

91. Morrow, A.; Dunstan, R.; Coombes, P. Elemental composition at different points of the rainwater harvesting system. Sci. Total Environ. 2010, 408, 4542-4548. [CrossRef]

92. USEPA. Guidelines for Water Reuse; USEPA: Washington, DC, USA, 2012.

93. Tricas, M.; Albert, R.; Bastian, R.; Nappier, S.; Regli, S.; Kasparek, L.; Gorke, R. Potable Reuse Compendium; United States Environmental Protection Agency: Washington, DC, USA, 2017.

94. Kasmin, H.; Bakar, N.; Zubir, M. Monitoring on the Quality and Quantity of DIY Rainwater Harvesting System. In IOP Conference Series: Materials Science and Engineering; IOP Publishing: Langkawi, Malaysia, 2016.

95. Struk-Sokołowska, J.; Gwoździej-Mazur, J.; Jadwiszczak, P.; Butarewicz, A.; Ofman, P.; Wdowikowski, M.; Kaźmierczak, B. The Quality of Stored Rainwater for Washing Purposes. Water 2020, 12, 252. [CrossRef]

96. Van Vliet, M.; Zwolsman, J. Impact of summer droughts on the water quality of the Meuse river. J. Hydrol. 2008, 353, 1-17. [CrossRef]

97. Vieira, A.S.; Beal, C.D.; Ghisi, E.; Stewart, R.A. Energy intensity of rainwater harvesting systems: A review. Renew. Sustain. Energy Rev. 2014, 34, 225-34242. [CrossRef]

98. Saidan, M.N.; Al-Weshah, R.A.; Obada, I. Potential rainwater harvesting: An adaptation measure for urban areas in Jordan. J. Am. Water Work. Assoc. 2015, 107, E594-E602. [CrossRef]

99. Morales-Pinzón, T.; Rieradevall, J.; Gasol, C.M.; Gabarrell, X. Modelling for economic cost and environmental analysis of rainwater harvesting systems. J. Clean. Prod. 2015, 87613-87626. [CrossRef]

100. James, K. Water issues in Australia-an LCA perspective. Int. J. Life Cycle Assess. 2003, 8, 242. [CrossRef]

101. Mushtaq, S.; Dawe, D.; Hafeez, M. Economic evaluation of small multi-purpose ponds in the Zhanghe irrigation system, China. Agric. Water Manag. 2007, 91, 61-70. [CrossRef]

102. Ghimire, S.R.; Johnston, J.M.; Ingwersen, W.W.; Hawkins, T.R. Life cycle assessment of domestic and agricultural rainwater harvesting systems. Environ. Sci. Technol. 2014, 48, 4069-4077. [CrossRef]

103. Leong, J.Y.C.; Balan, P.; Chong, M.N.; Poh, P.E. Life-cycle assessment and life-cycle cost analysis of decentralised rainwater harvesting, greywater recycling and hybrid rainwater-greywater systems. J. Clean. Prod. 2019, 229, 1211-1224. [CrossRef]

104. Morey, A.; Dhurve, B.; Haste, V.; Wasnik, B. Rainwater harvesting system. Int. Res. J. Eng. Technol. 2016, 3, 2158-2162.

105. Coombes, P.J.; Kuczera, G. A sensitivity analysis of an investment model used to determine the economic benefits of rainwater tanks. In Proceedings of the 28th International Hydrology and Water Resources Symposium: About Water; Symposium Proceedings, Wollongong, Australia, 10-13 November 2003; Institution of Engineers: Canberra, Australia, 2003.

106. Christian Amos, C.; Rahman, A.; Mwangi Gathenya, J. Economic analysis and feasibility of rainwater harvesting systems in urban and peri-urban environments: A review of the global situation with a special focus on Australia and Kenya. Water 2016, 8, 149. [CrossRef]

107. Espíndola, J.A.G.; Cordova, F.; Flores, C.C. The importance of urban rainwater harvesting in circular economy: The case of Guadalajara city. Manag. Res. Rev. 2018, 41, 533-553. 
108. Huang, C.-L.; Hsu, N.-S.; Wei, C.-C.; Luo, W.-J. Optimal spatial design of capacity and quantity of rainwater harvesting systems for urban flood mitigation. Water 2015, 7, 5173-5202. [CrossRef]

109. Jamali, B.; Bach, P.M.; Deletic, A. Rainwater harvesting for urban flood management-An integrated modelling framework. Water Res. 2020, 171115372. [CrossRef]

110. Woltersdorf, L.; Jokisch, A.; Kluge, T. Benefits of rainwater harvesting for gardening and implications for future policy in Namibia. Water Policy 2014, 16, 124-143. [CrossRef]

111. Das, A.; Munda, G.; Thakur, N.A.; Yadav, R.; Ghosh, P.; Ngachan, S.; Bujarbaruah, K.; Lal, B.; Das, S.; Mahapatra, B. Rainwater harvesting and integrated development of agri-horti-livestock-cum-pisciculture in high altitudes for livelihood of Tribal farmers. Indian J. Agric. Sci 2014, 84, 643-649.

112. Dey, N.C.; Bala, S.K.; Hayakawa, S. Assessing the economic benefits of improved irrigation management: A case study in Bangladesh. Water Policy 2006, 8, 573-584. [CrossRef]

113. Taib, Z.M.; Jaharuddin, N.S.; Mansor, Z. A Review of Flood Disaster and Disaster Management in Malaysia. Int. J. Account. Bus. Manag. 2016, 4, 97-105.

114. Gwenzi, W.; Nyamadzawo, G. Hydrological impacts of urbanization and urban roof water harvesting in water-limited catchments: A review. Environ. Process. 2014, 1, 573-593. [CrossRef]

115. Baguma, D.; Loiskandl, W.; Jung, H. Water management, rainwater harvesting and predictive variables in rural households. Water Resour. Manag. 2010, 24, 3333-3348. [CrossRef]

116. Mohamad, S.; Mohammad, M.F.; Yusof, M.R.; Musa, M.F. The Awareness Among Developers on Rainwater Harvesting System (RWHS). Int. Colloqium N Sci. Technol. 2014, 2014, 97-102.

117. Nations, U. Sustainable Development Goals Report, New York, USA. Available online: https://unstats.un. org/sdgs/report/2017/ (accessed on 10 November 2020).

118. HO, M.S.; Suhaimi, A.; Rasyikah, M.; Ahmad Jamaluddin, S.; Huang, Y.; Farah, M. Policies and Incentives for Rainwater Harvesting in Malaysia; Rainwater Utilization Colloquium; NAHRIM Mini Auditorium: Kuala Lumpur, Malaysia, 2007.

119. Ahmed, W.; Gardner, T.; Toze, S. Microbiological quality of roof-harvested rainwater and health risks: A review. J. Environ. Qual. 2011, 40,13-21. [CrossRef]

120. Schuetze, T. Rainwater harvesting and management-policy and regulations in Germany. Water Sci. Technol. Water Supply 2013, 13, 376-385. [CrossRef]

121. Dolnicar, S.; Hurlimann, A.; Grün, B. Water conservation behavior in Australia. J. Environ. Manag. 2012, 105, 44-52. [CrossRef]

122. Ghisi, E.; da Fonseca Tavares, D.; Rocha, V.L. Rainwater harvesting in petrol stations in Brasilia: Potential for potable water savings and investment feasibility analysis. Resour. Conserv. Recycl. 2009, 54, 79-85. [CrossRef]

123. World Health Organization; World Plumbing Council. Health Aspects of Plumbing; World Health Organization: Geneva, Switzerland, 2006.

124. Deshkar, S.; Thanseeh, R.; Menon, V.G. A review on IoT based m-Health systems for diabetes. Int. J. Comput. Sci. Telecommun. 2017, 8, 13-18.

125. Lasya, B.; Bhavana, Y.; Deekshitha, B.; Priya, B. An Innovative and Effective Electronic Based Automatic Rainwater Harvesting System. In Proceedings of the 2020 Third International Conference on Smart Systems and Inventive Technology (ICSSIT), Tirunelveli, India, 20-22 August 2020; IEEE: New York, NY, USA, 2020.

126. Vinoj, J.; Gavaskar, D.S. Smart City Rain Water Harvesting (IOT) Techniques. Int. J. Sci. Dev. Res. 2018, 3, 1-6.

127. Oberascher, M.; Zischg, J.; Palermo, S.A.; Kinzel, C.; Rauch, W.; Sitzenfrei, R. Smart rain barrels: Advanced LID management through measurement and control. In International Conference on Urban Drainage Modelling; Springer: Berlin/Heidelberg, Germany, 2018.

128. Palermo, S.A.; Talarico, V.C.; Pirouz, B. Optimizing rainwater harvesting systems for non-potable water uses and surface runoff mitigation. In Proceedings of the International Conference on Numerical Computations: Theory and Algorithms, Crotone, Itally, 15-21 June 2019; Springer Cham: New York, NY, USA, 2019.

Publisher's Note: MDPI stays neutral with regard to jurisdictional claims in published maps and institutional affiliations. 